ISSN: $2318-1966$

v. 3, n. 3

jan - jun 2015

\title{
Dossiê
}

\section{ISTO NÃO É UM MANUAL DE INSTRUÇÕES: NOTAS SOBRE A CONSTRUÇÃO E CONSUMO DE PERFIS EM TRÊS REDES GEOSOCIAIS VOLTADAS AO PÚBLICO GAY}

\author{
Felipe Padilha \\ Doutorando no Programa de Pós-Graduação \\ em Sociologia da Universidade Federal de São Carlos
}

\begin{abstract}
RESUMO
Este artigo deseja compreender a dinâmica entre as plataformas que criam redes sociais digitais e os seus usuários. $\mathrm{O}$ argumento está estruturado em três partes: inicialmente exponho o contexto de criação dos aplicativos geossociais apontando para as relações que dão plausibilidade à sua produção; em seguida, abordo como são apresentadas as propagandas desses produtos para o público potencialmente consumidor e, por fim, reflito sobre as relações implicadas na atividade de construir um perfil nessas plataformas. Pensando na dimensão arquitetural dos aplicativos, alio a etnografia em curso com homens que buscam parceiros amorosos e sexuais por meio das mídias digitais, para discutir a ressonância entre a relação desenvolvida pelos usuários, as mensagens veiculadas pela propaganda e os contextos culturais nos quais essas tecnologias são usadas.
\end{abstract}

Palavras-chave: Aplicativos geossociais. Mídias digitais. Propaganda. Relações homoeróticas.

\begin{abstract}
This paper aims to understand the dynamics surrounding the platforms that create digital social networks and their users. The argument is structured in three parts: initially expose the context of creating geosocial applications pointing to the relationships that give plausibility to their production; then aboard as advertisements for these products are presented to potentially consuming public are displayed and eventually reflect on the relationships involved in the activity to construct a profile on these platforms. Thinking about the architectural dimension of applications, allying the ongoing ethnography with men seeking romantic and sexual partners through digital media, to discuss the resonance between the relationship developed by users, the messages conveyed by advertising and the cultural contexts in which these technologies are used.
\end{abstract}

Key-words: Geosocial applications. Digital media. Advertising. Homoerotic relationships. 
Isto não é um manual de instruções: notas sobre a construção e consumo de perfis em três redes geosociais voltadas ao público gay

\section{Introdução}

As reflexões aqui apresentadas são resultados preliminares de uma etnografia em curso com homens que buscam parceiros amorosos e sexuais por meio das mídias digitais. Especificamente, os interlocutores tem idade entre 18 e 65 anos e residem ou transitam por 24 cidades localizadas na região de São Carlos, interior do estado de São Paulo. Todos fazem uso de três redes geossociais ${ }^{1}$, voltados ao público gay, visando de estabelecer contatos com parceiros sexuais e/ou amorosos.

Neste artigo estou interessado em refletir sobre a dinâmica que se dá entre as plataformas das redes sociais digitais e os usuário. O argumento está estruturado em três partes: inicialmente exponho o contexto de criação dos aplicativos apontando para as relações que dão plausibilidade à sua criação; em seguida, abordo como são apresentadas as propagandas desses produtos aos usuários e, por fim, reflito sobre as relações implicadas na atividade de construir um perfil nessas plataformas.

Considero que esses aplicativos criam possibilidades de relacionamento e que uma compreensão sobre os usos precisa levar em consideração a dimensão cultural que dá plausibilidade para que esses produtos sejam imaginados, criados, recebidos, apropriados e consumidos em diferentes contextos. Dito isto, é possível sugerir que essas tecnologias são criadas e moldadas respondendo também às condições históricas de um contexto que não provê condições de reconhecimento e segurança para as expressões públicas do desejo homoerótico, ou não-heterossexual. Por outro lado, os usuários em contato com a tecnologia podem constantemente ressignificar o seu uso.

Minha intenção ao abordar a arquitetura dessas plataformas, ou seja, a interface e as potencialidades imaginadas pelos seus desenvolvedores, tem como pano de fundo o interesse em compreender como é articulada a ressonância entre as mensagens veiculadas pela propaganda, os usos e os contextos culturais nos quais essas tecnologias são produzidas e recepcionadas.

Partilho da visão da socióloga marroquina Eva Illouz (2014, p. 34) para quem "a

\footnotetext{
1 Por redes geossociais me refiro a um conjunto específico de aplicativos que operam como redes sociais digitais georreferenciadas. São tecnologias que operam em dispositivos que suportam o sistema de posicionamento global (GPS). Por sua vez, a noção de mídias digitais aqui mobilizada aponta para o conjunto articulado de tecnologias da informação e seus suportes que englobam, principalmente, os dispositivos tecnológicos que permitem o acesso à internet, tais como computadores, smartphones e tablets. Em síntese, uma das características principais das mídias digitais é transformar sequências de números que podem ser interpretados por um computador.
} 
ressonância significa o uso e o reconhecimento de algo familiar". Essa perspectiva coloca em destaque o modo como são articulados os valores sociais centrais e as experiências chave para os contextos culturais em que livros, filmes, jogos, softwares, aplicativos e outros produtos circulam e ganham visibilidade atraindo a atenção e o gosto de milhares de consumidores.

Nas lojas virtuais em que aplicativos desse tipo são disponibilizados há mais de uma dezena de concorrentes similares prometendo "ser diferentes" e disputando os cliques 2 . Três deles são bastante conhecidos pela audiência brasileira: Grindr@, Scruff@ e Hornet@ o Grindr@ tenha sido o primeiro lançado no mercado, em 2009, todos foram produzidos em um curto período de tempo mediante uma perspectiva concorrencial, haja vista o nicho de consumo encontrado pelo predecessor ${ }^{3}$. Todos operam em dispositivos móveis, como tablets e smartphones, desde que possuam suporte para a tecnologia do sistema de posicionamento global (GPS). De modo sintético, a funcionalidade central dos aplicativos é a produção de redes sociais digitais georreferenciadas que apresentam as possibilidades de contato entre os usuários de acordo com a distância e o posicionamento geográfico entre eles.

Inicialmente tomo a propaganda como uma tecnologia social mediadora da imagem do produto que se pretende vender e, portanto, pensada com o objetivo de estabelecer um primeiro contato entre o usuário e o produto. Com isso, pretendo acessar o modo como os aplicativos são imaginados, nomeados e classificados de acordo com o público, como as suas funcionalidades são dispostas considerando as expectativas que se tem sobre a audiência até alcançar a maneira como são apresentados pelo discurso publicitário.

Em seguida, abordo a articulação entre o discurso publicitário, a pornografia gay convencional e o conjunto de interpelações que guia a manufatura de um perfil nesses aplicativos. Isso permitirá compreender melhor as relações entre as categorias pré-formatadas,

\footnotetext{
2 Até o momento identifiquei outros dezesseis aplicativos com funções similares aos três abarcados pelo recorte, são eles: GuySpy, Badoo, Growlr, BoyAhoy, Bender, Jack'd, Gaydar, Disponivel.com, Recon, PlanetRomeo, u4Bear, Gay.com, Maleforce, Manhunt.com, Daddyhunt, Gfinder, HardLine. Durante algum tempo mantive as redes no meu smartphone, mas percebi que, na região onde pesquiso, o número de usuários é pequeno ou inexistente em alguns casos. Isso me levou a compreender melhor o uso dos três aplicativos abarcados pelo recorte, inclusive porque quase todos os usuários com quem mantive contato possuíam perfis também em uma das redes que eu estudava.

${ }^{3}$ É possível dizer que esses aplicativos estão inseridos no contexto do que autoras como Baym (2013) tem chamado de "web 2.0". A "web 1.0" remete ao tipo de conteúdo produzido no final da década de 1999 e inicio dos 2000 e cuja principal característica era a produção desenvolvida e alimentada pelos provedores e sites. Aos usuários e às usuárias cabia a tarefa de acessar as produções ali disponibilizadas. Um dos deslocamentos proporcionados por essa nova internet chamada 2.0 é o fato de ser gerada pelo usuário, mas gerida por profissionais para gerar lucros. Essa mudança está diretamente ligada ao barateamento e proliferação dos equipamentos de audio e video, sobretudo após a chegada dos smartphones ao mercado. Com câmeras e funcionalidades de audio e video acoplados, esses equipamentos marcaram a passagem para um tipo de comunicação produzida e disponibilizada pelos usuários, mas que é gerida pelos sites como, por exemplo, o YouTube.
} 
Isto não é um manual de instruções: notas sobre a construção e consumo de perfis em três redes geosociais voltadas ao público gay

portanto, infraestruturais, oferecidas para que o usuário descreva a si mesmo e se construa na rede. Nesse movimento, considero a centralidade da fotografia como texto e gramática que regula os corpos e desejos. A intenção é delinear os termos em que se dão as negociações sobre as diferenças corporais, geracionais, estéticas, étnico-raciais, de renda, estilo de vida, educacionais e nacionais como questões implícitas à construção de um perfil.

Por fim, em diálogo com os estudos queer, os estudos brasileiros sobre sexualidade e os estudos sobre mídias digitais, discuto como o a internet e as mídias digitais têm impactado a gramática que regula a circulação de imagens, referenciais, valores e vocabulários mobilizados para experienciar o desejo e a autoimagem.

\title{
A ressonância da propaganda
}

\begin{abstract}
Grindr é um aplicativo diferente porque é descomplicado e feito para ajudar os usuários a conhecer pessoas enquanto estão em movimento. Não é como um site de busca de relacionamentos que toma horas do seu tempo construindo perfis a partir de questionários psicológicos complexos e invasivos. O Feet Away, não é apenas um slogan que usamos em nossas camisetas. É um estado de espírito, um estilo de vida, uma nova experiência para encontrar pessoas. Nossa missão é materializar offline a pessoa com quem você ainda há pouco estava conversando. ${ }^{4}$
\end{abstract}

O excerto acima foi extraído da página eletrônica mantida na internet pela equipe responsável pelo Grindr@. Este aplicativo foi criado por Joel Simkhai, um jovem israelense radicado nos Estados Unidos da América. De modo simplificado, trata-se de um software desenvolvido para homens interessados em buscar e estabelecer contatos com possíveis parceiros amorosos e/ou sexuais.

Ainda que pareça original, a criação de Simkhal pode ser vista como um aperfeiçoamento dos "antigos" sites especializados na busca de parceiros. Esses sites, anteriores a difusão do GPS, operavam situando geograficamente os usuários de acordo com o código de endereçamento postal. Essa estratégia que permitia o contato entre pessoas próximas ou localizadas a partir de uma área restrita foi chamada de craigslist. Trata-se de uma rede de comunidades online centralizadas que disponibilizavam anúncios gratuitos aos usuários. O conteúdo anunciado variava desde ofertas de empregos até conteúdo erótico.

Os antigos sites de buscas de parceiros como o Disponível.com e o Manhunt.com

\footnotetext{
4 Tadução minha. Disponível em: 〈www.grindr.com>.
} 


\section{NORUS - v3, n.3, jan-jun 2015.}

também operavam a partir de uma dimensão geográfica. Em sites desse tipo filtros de busca que dividiam os usuários de acordo com a cidade sempre foram recursos operativos. Do mesmo modo, nas salas de bate-papo as divisões regionais, ao lado das preferências eróticas, também tiveram destaque. Ao incorporar o georreferenciamento como base central para a oferta e composição de possíveis contatos os aplicativos aceleraram e dinamizaram a busca.

Em uma rede social digital as relações criam as redes e os perfis produzidos pelos usuários compõe o conteúdo central. Nancy Baym (2010), pesquisadora das mídias digitais, aponta que a manutenção de relacionamentos pessoais foi desde sempre um dos usos mais populares da internet. Mas, considerando que esses aplicativos foram criados por homens gays para outros homens gays, é necessário situar a compreensão a partir de uma visão que os insira na história da busca de parceiros por pessoas do mesmo sexo.

Vistos desta perspectiva, os aplicativos podem ser articulados à história pós-Revolução Sexual e às restrições que historicamente enlaçam as pessoas que buscam relações homoeróticas. Os aplicativos desnudam outras formas de sociabilidade e visibilidade que se desdobram a partir da popularização das mídias digitais e dos seus usos. Há uma estreita ligação entre os usos dos aplicativos e as restrições morais com as quais se deparam as pessoas que buscam estabelecer relações fora da hegemonia heterossexual. Esse tipo de injustiça tem permanecido pouco ou nada reconhecida e tampouco analisada, especialmente fora dos grandes centros urbanos.

Os aplicativos podem ser vistos em continuidade com o cruising, a antiga deriva ou perambulação por territórios reconhecidos e/ou codificados como tolerantes às práticas do sexo impessoal entre homens como, por exemplo, banheiros públicos e parques ${ }^{5}$. Autores como Richard Miskolci (2014) analisam o hook-up como uma versão contemporânea do cruising, mas higienizada por meio das mídias digitais. Dessa perspectiva, o hook-up - ou "fast-foda", numa transposição para os termos dos interlocutores brasileiros - é parte de um arranjo que articula as condições morais dos contextos locais ao arranjo sociotécnico dos aplicativos como uma solução provisória e imperfeita para a falta de segurança e reconhecimento.

Miskolci (2015, p.63) chama atenção para o fato de que quando criou o aplicativo

\footnotetext{
${ }^{5}$ Para algumas análises que marcaram as interpretações sobre o cruising ver: Humpreys, Laud. Tearoom Trade: impersonal sex in public places, New York, Aldhine/Athenton, 1971; Perlongher, Néstor. O negócio do michê: a prostituição viril em São Paulo. São Paulo. Editora Perseu Abramo. 2008.
} 
Isto não é um manual de instruções: notas sobre a construção e consumo de perfis em três redes geosociais voltadas ao público gay

Simkhai residia em Los Angeles, até hoje cidade sede da empresa, "conhecida por "não ter centro', ou seja, por ser espalhada e sem pontos de referência para a sociabilidade cotidiana em espaços públicos".

Desde que foi lançado, este aplicativo rapidamente se tornou conhecido entre homens gays conectados às mídias digitais se espalhando ao redor do mundo. Atualmente, os textos publicitários contidos no site oficial anunciam que mais de dois milhões de usuários distribuídos em 196 países utilizando o Grindr@6 ${ }^{6}$. Simkhai, em entrevistas, costuma afirmar que "não tinha planos de mudar uma cultura"7, valendo-se da extensão do uso sinalizada pelo grande volume de downloads ${ }^{8}$.

É possível ponderar que Simkhai, assim como Oprah Winfrey, pode ser interpretado como um desses

empreendedores culturais que por razões biográficas e estruturais estão posicionados em um ponto de encontro entre as contradições presentes no centro das formações estruturais modernas desfrutando de maiores possibilidades de produzir fórmulas culturais poderosas (Illouz, 2014, p.37).

Os discursos publicitários empreendidos pelos anunciantes não estão de fora desse jogo de poder e produção de fórmulas culturais. Esses discursos mantém a ênfase na simplicidade, jogando com o interesse pelo inesperado e com a sensação de autonomia que as redes sociais georeferenciadas prometem ao usuário. As características mercadológicas dessas ferramentas são produzidas em consonância com o ideário liberal de indivíduo na medida em que a autonomia é anunciada e vendida como a grande promessa.

Também persiste entre as empresas concorrentes o desejo de despertar a curiosidade dos possíveis clientes apresentando a expansão de funcionalidades, principalmente aquelas que são disponibilizadas mediante pagamento. Além disso, é frequente que cada aplicativo centre seu alvo em segmentos específicos do público gay como, por exemplo, ursos ou adeptos de práticas sexuais como bondage e sadomasoquismo.

Iara Beleli (2007, p.194) explica que "uma propaganda eficaz é aquela que oferece a

\footnotetext{
${ }^{6}$ Estatística disponível no site do Grindr.

7 “You know, I never had any master plan to shift a culture. I made something because I wanted it for myself". A entrevista completa com Simkhai está disponível em: 〈http://www.nytimes.com/2014/12/14/fashion/the-sex-education-of-grindrs-joelsimkhai.html>.

${ }^{8}$ Uma noticia recentemente veiculada pelo site da BBC afirma que no Paquistão, país conhecido pelas perseguições à homossexuais, o aplicativo tem sido usado por homens para burlar a vigilância promovendo encontros e festas secretas. Disponível em: www.bbc.co.uk/portuguese/noticias/2013/09/130827 gay pakistan mv.shtml. Acesso em 2014 de julho de 2015.
} 


\section{NORUS - v3, n.3, jan-jun 2015.}

‘sensação' de que o consumidor está escolhendo livremente um modo de ser”. A partir da etnografia em curso, tenho percebido que as promessas aplicativos vão ao encontro de uma das demandas mais recorrentes na fala dos meus interlocutores: a autonomia.

O desejo de autonomia, com frequência, remete às condições da busca por parceiros e às experiências moldadas por restrições morais e materiais profundas que implicam em vidas que são vigiadas. Os aplicativos vêm se somar às restrições sociais e ao desejo de autonomia como tecnologias conformadoras dos usuários, ou seja, elas são parte de um arranjo sociotécnico provisório e precário que busca lidar com questões - e restrições - morais e políticas.

Uma vez conectado à internet, o usuário pode acessar uma grade com perfis de outros usuários apresentados mediante o critério de proximidade física. Dito isto, é possível destacar que uma relação espacial entre o aplicativo e as possibilidades de contato, constantemente remodeladas de acordo com o deslocamento do usuário, dai o aspecto geossocial dessas redes. De certo modo, esses artifícios que acabam por modelar um tipo de "geografia erótica" (GADELHA, 2015).

Proponho uma compreensão dos aplicativos como "tecnologias do gênero", no sentido proposto pela feminista Teresa de Lauretis (1996), na medida em que são regulados por uma economia política que arranja suas práticas e os seus usos em torno de convenções correntes. Dessa perspectiva, o gênero é entendido como uma relação social constantemente refeita por meio de várias tecnologias e discursos institucionais que disputam o controle dos campos de significação social para então produzir, promover e implantar determinadas formas inteligíveis de representar o próprio gênero. Lauretis permite uma mirada sobre o gênero em seu processo de construção tomando-o como o produto e como o processo da sua própria representação. Em síntese, "a construção do gênero é o produto e o processo de ambas, da representação e da auto-representação" (1996, p. 15).

Como toda mercadoria que disputa a atenção de consumidores entretidos com a disponibilidade de uma vasta oferta de produtos similares, os aplicativos apostam no poder das peças publicitárias para aguçar a curiosidade da audiência. Os anúncios circulam principalmente em sites direcionados ao público gay. A propaganda, enquanto um discurso, pressupõe o público que interpela colocando em circulação uma imagem mais ou menos esperada uso. Para "funcionar", a ela precisa "refazer constantemente o significado e a 
Isto não é um manual de instruções: notas sobre a construção e consumo de perfis em três redes geosociais voltadas ao público gay

experiência da vida para a sua audiência” (WAGNER, 2010, p. 112). Nas palavras de Wagner, “a propaganda vende seus produtos 'vendendo' sua objetificação dos produtos, sua imagem de uma vida que os inclui" (p.111).

Analisando a formação do discurso publicitário, Felip Vidal Auladell aponta que "o consumo de mercadorias, mediante sua imagem, alcança todas as esferas da vida cotidiana de modo que a comercialização de experiências congrega ou, quando menos, persegue uma expansão cultural diante da colonização de toda a vivência” (2014, p. 180). Imersos em uma perspectiva concorrencial, as propagandas desses aplicativos imaginam públicos consumidores reconhecidos como distintos. Desse modo, o discurso publicitário cria o público que nomeia e interpela.

A segmentação entre o público consumidor veiculada nos anúncios é imaginada tendo como base na taxinomia comercial moldada a partir de práticas e identidades sexuais produzidas pela indústria da pornografia convencional com sede nos Estados Unidos da América. Elas são parte da herança estética deixada pelas mídias pré-digitais como os filmes produzidos pela indústria pornográfica gay mainstream e revistas dirigidas a esse público.

Nos anúncios que figuram nas páginas mantidas por esses três aplicativos na $w e b^{9}$ é comum a apresentação de imagens ilustradas por rapazes jovens, loiros, com olhos claros, tez branca, alguns exibindo corpos esculpidos, depilados ou peludos e que denotam os exercícios físicos e um estilo tipicamente considerado saudável para as convenções estadunidenses. Homens considerados gordos ou magros demais, negros e orientais não fazem parte do imaginário dessas peças publicitárias.

\footnotetext{
${ }_{9}^{9}$ As páginas eletrônicas dos aplicativos são: Grindr www.grindr.com; Scruff www.scruff.com; Hornet http://gthrnt.com/.
} 
Figura 1 - Site do aplicativo Grindr na web.

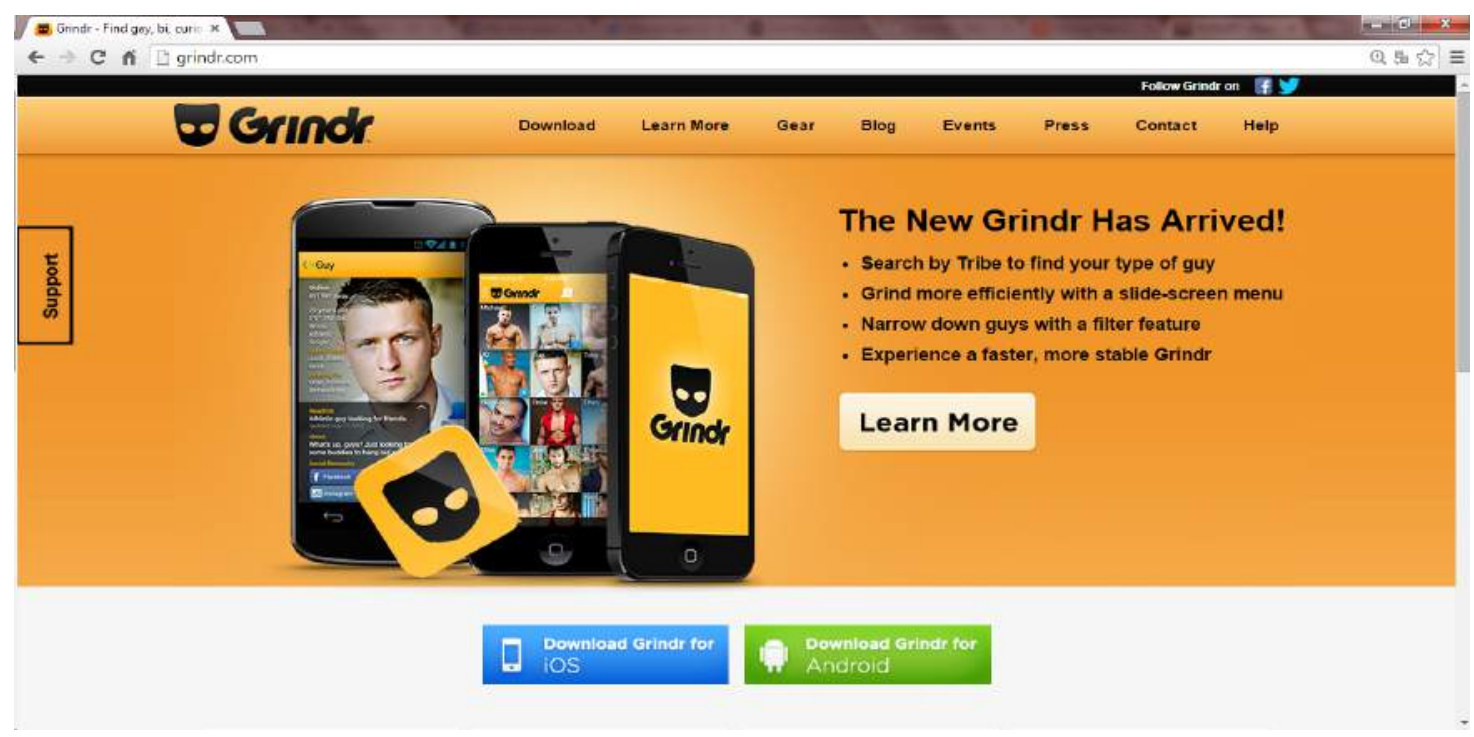

Fonte: Disponível em: 〈www.grindr.com>.

Ao colocar em circulação um vocabulário que reproduz a segmentação do público gay pensado pela indústria pornográfica gay convencional, a publicidade dos aplicativos estende esse imaginário para outros contextos através do tráfego de informações criando articulações entre representações que extrapolam as fronteiras nacionais. Esse deslocamento põe em circulação ícones visuais, comportamentos e legislações apresentados quase sempre como universalizáveis, já que modelares.

Nesse processo, em alguns contextos, como é o caso da região do interior paulista que analisei na dissertação de mestrado (PADILHA, 2015), essa circulação proporciona fissuras e tensões no vocabulário empregado para qualificar o desejo e que, por vezes, acabam fomentando disputas em torno dos códigos convencionalmente empregados para falar do gênero e da (homo)sexualidade. Tenho percebido que essa batalha simbólica, semiótica e estética, quando ocorre em espaços restritos como os aplicativos, ganha projeção principalmente quando expressa pela rejeição ou pela ironia.

As imagens veiculadas nos anúncios são representativas dos corpos pensados como apresentáveis e, intuitivamente, como desejáveis nessas mídias. Essas mesmas imagens e peças publicitárias são veiculadas nas páginas dos aplicativos na loja virtual. O poder dessa imagética pode ser percebido nas similaridades encontradas entre os perfis produzidos em 
Isto não é um manual de instruções: notas sobre a construção e consumo de perfis em três redes geosociais voltadas ao público gay

diferentes partes do mundo ${ }^{10}$. Tanto os perfis produzidos pelos usuários em diferentes lugares, quanto a a publicidade dos aplicativos tomam a pornografia gay convencional como referencial simbólico.

No entanto, há que se considerar que o foco das imagens centrado no tornos, nos braços e no abdômen são efeitos da proibição, em 2009, da exposição de imagens consideradas "pornográficas" nos perfis. A decisão em torno da proibição foi o resultado de negociações entre empresas como a Apple e o governo dos Estados Unidos da América. Essa discussão tinha como pano de fundo o pânico moral em torno da circulação de imagens íntimas por aplicativos de mensagens, prática conhecida como sexting. Nesse caso, a preocupação central se deu em torno da possibilidade de que tal prática facilitasse o acesso das crianças às imagens, podendo eventualmente funcionar como facilitador da pedofilia ${ }^{11}$. Essas relações permitem deslindar as articulações entre estética, desejo e apresentação de si e a regulação estatal.

Susanna Paasonen (2013) aponta o fato de que a internet, pelo seu caráter interativo e mais acessível a pequenos produtores, propiciou o crescimento da pornografia amadora. Nesse cenário, a web se converteu em um terreno fértil para a esse tipo de pornografia na medida em que permitiu a criação, execução, distribuição e confecção de sites próprios para o compartilhamento de imagens e vídeos - de forma gratuita ou paga e com preços variados.

A dimensão arquitetural que se interpõe na relação entre o usuário e os aplicativos permite olhar para a articulação entre a autoimagem e a aceitação social. Como pano de fundo, partilho da perspectiva de Miskolci (2015) para quem a busca por parceiros por meio do uso dessas tecnologias é envolvido por um contexto social hostil que cria um tipo de uso articulado com a dependência de imagens modelares veiculadas pelas mídias.

Considero que imagens modelares veiculadas pelas mídias cotidianamente são dados culturais que podem ser compreendidas em um sentido mais amplo do que simplesmente um enredo mercadológico. Um bom exemplo disso pode ser visto na abordagem analítica

\footnotetext{
10 A esse respeito chamo a atenção para o fato de que, desde que iniciei a pesquisa, junto com meu orientador, temos percebido uma certa regularidade nos perfis observados em diferentes partes do mundo. Tanto no Japão, quanto na Inglaterra e no Mato Grosso do Sul, por exemplo, é regular a apresentação do torso e do abdômen como ícones que sinalizam um tipo de vida considerada "saudável" que, por sua vez, engendra a construção de um tipo corporal específico.

${ }^{11}$ Diversas notícias e reportagens podem ser encontradas na internet sobre as discussões que se desenvolveram nesse período. Como exemplo desse movimento ver: http://blogs.estadao.com.br/marcos-guterman/sexting-vira-epidemia-nos-eua/
} 


\section{NORUS - v3, n.3, jan-jun 2015.}

proposta por Maria Inés Landa (2011) sobre as relações culturais entre o fitness ${ }^{12}$ e o ethos empresarial emergente. Essas relações operam como um diagrama para a compreensão de uma ordem corporal e cultural que progressivamente tem adquirido centralidade no mundo globalizado.

As análises robustas de Landa permitem compreender como os saberes normalizadores produzidos pelas ciências do treinamento, pela medicina desportiva, pelos discursos publicitários e pelas teorias do management condicionam os processos de produção, seleção, normalização, disciplinamento, controle, invisibilização e exclusão dos corpos que inscrevem a vidas dos sujeitos contemporâneos em emaranhados temporais de caráter global.

Landa (2011, p.269) aponta que, para ter efetividade, a ampliação do repertório “saudável” empreendido pelo fitness se fez articulado à mídia. Nesse cenário, figuras como Jane Fonda (atriz) e Kenneth Cooper (médico) entronizaram hiperbolicamente o enfoque espetacular do indivíduo-individuado fomentando uma articulação inédita entre discursos biologizantes e econômico-empresariais. Essa junção impactou na aceitação global de um modo de vida que associa a felicidade e o êxito com hiperatividade, adaptabilidade, flexibilidade, auto-regulação e sobrevivência. Esse ideário se tornou "funcional" na medida em que foi capaz de instrumentalizar sujeitos que operam em um mundo que se apresenta tendencialmente incerto e mutável, suscetível aos imperativos da acumulação de capitais.

A imagem sustentada pelo discurso publicitário a partir da década de 1980 levou o sonho de Jane Fonda a uma cruzada planetária. A publicidade, acionando o imaginário moderno enraizado no progresso e na crença na elegibilidade, não faz referência a um corpo que se possui, se exibe ou se "é". Considerando o marco em que atualmente opera, o que a propaganda exibe como saudável remete a uma ação performada em um espaço que é uma academia (LANDA, 2011, p.248).

As propagandas, assim como os aplicativos, possuem também uma dimensão “tecnológica” (LAURETIS, 1996) na medida em que apresentam uma recriação de um espaço possível de ser habitado e desejado pelos olhos de quem as consome. As propagandas são ferramentas poderosas na medida em que fornecem de antemão uma representação do objeto possibilitando um contato primário do usuário com um repertório e uma retórica visual do

\footnotetext{
12 Esta autora entende o fitness como um "dispositivo cultural" que congrega práticas discursivas e corporais de alcance global e, que traz em si, as marcas dos ideários que, na contemporaneidade, atravessam as sociedades euro-americanas entrelaçadas à mundialização.
} 
Isto não é um manual de instruções: notas sobre a construção e consumo de perfis em três redes geosociais voltadas ao público gay

produto. Ainda assim, há que se considerar que essas tecnologias efetivamente criam um espaço relacional possível para pessoas que - de outra maneira - pouca ou nenhuma socialização teria. Não se trata de apenas uma promessa ou uma enganação mercadológica.

Assim como Simkhai, foi a partir das "listas de classificados online" que Johnny Skandros imaginou o seu próprio aplicativo ${ }^{13}$. Como uma crítica à maioria dos usuários do concorrente, ao mesmo tempo como efeito da segmentação do mercado, Skandros, em 2011, lançou o Scruff@. Segundo ele, um dos seus objetivos naquele momento era apresentar uma possibilidade para os caras mais velhos que, assim como ele, não se reconheciam no Grindr@. O próprio termo que nomeia o aplicativo, "scruff", poderia ser traduzido como "desleixado" ou "largado", perfil que seu criador atribui a si e ao que buscava para um possível encontro naquele momento.

Figura 2 - Site do aplicativo Scruff na web.

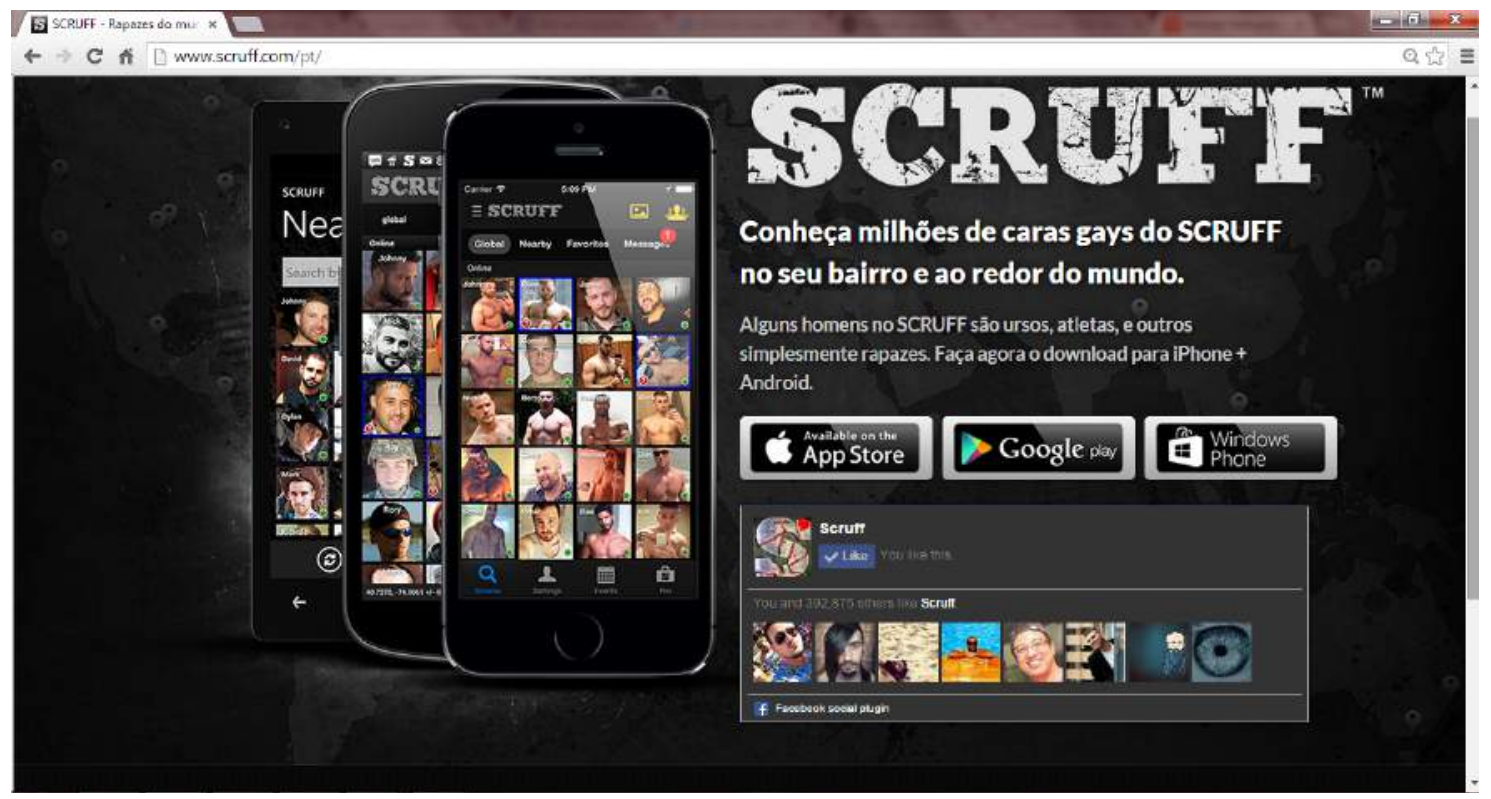

Fonte: Disponível em: 〈www.scruff.com/pt $\rangle$.

No discurso publicitário oficial produzido em torno do Scruff@ o foco recai sobre a imagem convencional do gay-urso dando visibilidade às imagens de homens fortes, em geral peludos e fisicamente robustos, vestindo trajes em couro ou jeans, com mais de trinta anos, mas sem com isso fechar espaço para outros públicos. No Scruff@ os usuários podem

\footnotetext{
${ }^{13}$ Entrevista disponível em: http://www.gaystarnews.com/article/meet-the-man-behind-scruff/. Acesso em 15 de setembro de 2015.
} 
NORUS - v3, n.3, jan-jun 2015.

notificar o interesse a partir de um "woof", uma espécie de marca ou "pegada" deixada em um perfil visitado e que demonstra o interesse.

Outra funcionalidade disponibilizada ao usuário por este aplicativo foi o acesso aos perfis que o visitaram e a possibilidade de vincular o perfil de um outro usuário ao seu facilitando a busca por casais. Foi permitida a publicação de mais de uma fotografia e foi aumentado o número de caracteres reservados ao texto descritivo. Por fim, a função "checkin" possibilitou deixar pegadas marcando também os lugares por onde os usuários transitam, tais como bares, boates, entre outros.

Em 2011, já com um grande número de adeptos, outros aplicativos como o Hornet@ incrementaram a concorrência entre os produtos. Durante toda a pesquisa, não encontrei referências à história da sua criação, exceto pelo fato de que a empresa é sediada na cidade de San Francisco. Ainda que o site oficial deste aplicativo disponibilize apenas informações de suporte técnico e ajuda, esta página virtual é a que mais enfatiza informações sobre a prevenção de Doenças Sexualmente Transmissíveis (DST), em especial, HIV. Além disso, esse é o aplicativo que oferece mais recursos para a interação na versão gratuita.

Figura 3 - Site do aplicativo Hornet na web.

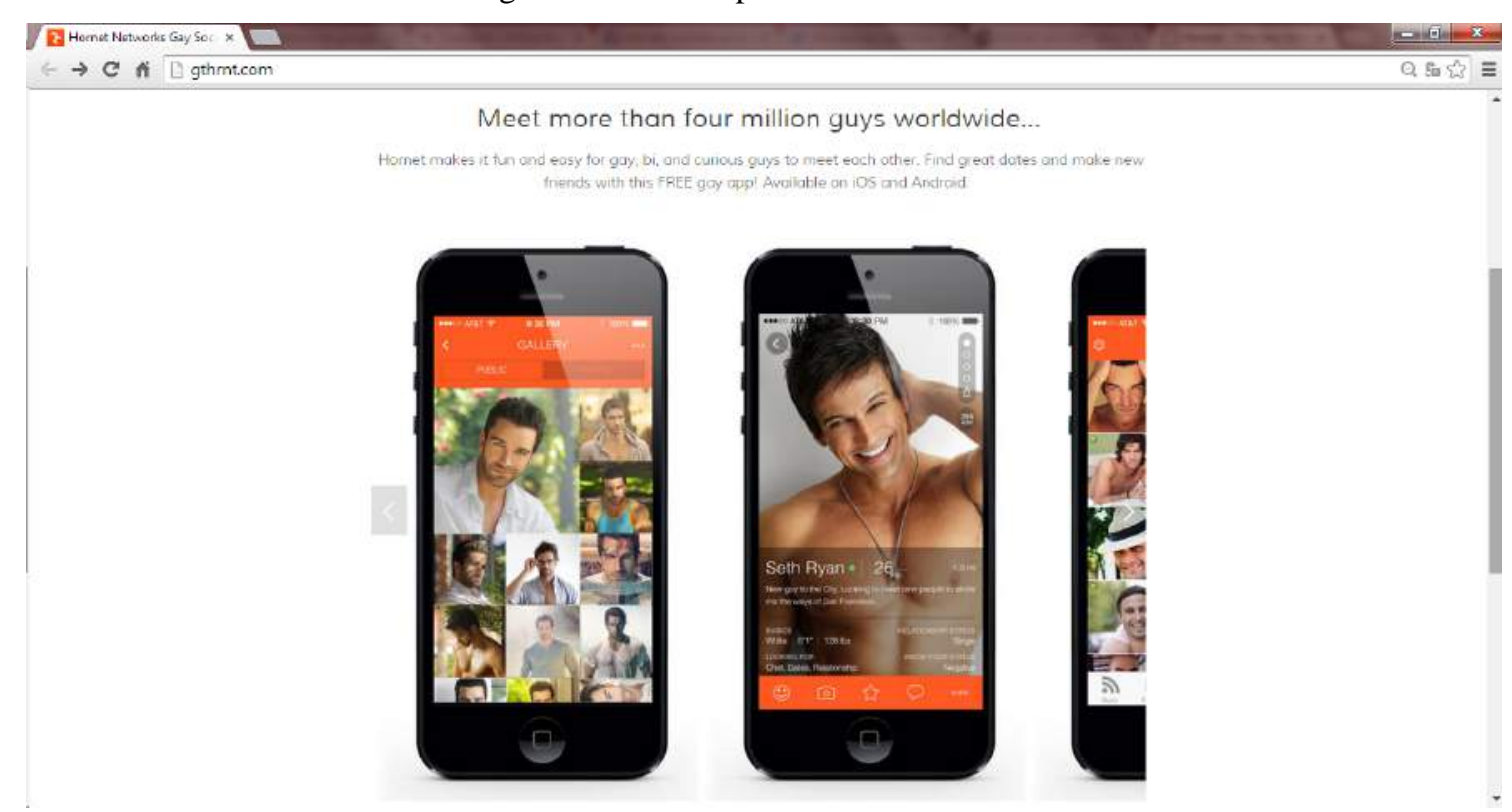

Fonte: Disponível em: 〈www.gthmt.com> 
Isto não é um manual de instruções: notas sobre a construção e consumo de perfis em três redes geosociais voltadas ao público gay

$\mathrm{Na}$ disputa dos aplicativos pela preferência dos usuários, a ampliação de recursos oferecidos de maneira gratuita é o principal atrativo. No caso do Hornet@, talvez o mais popular entre os três, é provável que seu sucesso se deva aos recursos expandidos em sua versão gratuita. Uma novidade foi permitir que o usuário procurasse novos contatos em qualquer região do mundo apenas localizando o endereço na barra "explorar". O álbum de fotografias expandido, contendo até oito quadros, e passou a suportar imagens com uma melhor resolução do que seus concorrentes. O último recurso recentemente disponibilizado foi o uso do aplicativo a partir de computadores conectando os usuários a partir do site.

Após a chegada do Hornet $(\bigodot$ ao mercado o Scruff $@$ redefiniu as funções concedidas na versão gratuita disponibilizando um recurso de exploração geográfica semelhante. Já o Grindr@, na versão gratuita, se manteve tradicionalmente fiel à simplicidade da primeira versão.

Figura 4 - Imagem da interface de "exploração". Hornet à esquerda e Scruff à direita.
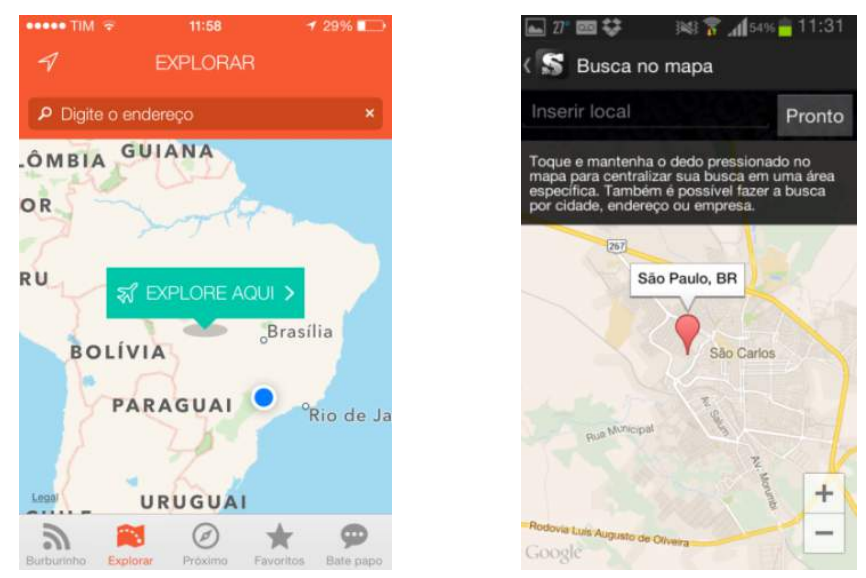

Fonte: Hornet e Scruff

As páginas oficiais dos aplicativos disponíveis na internet apontam para a articulação entre desejo e consumo, na medida em que cabe discurso publicitário a missão de fazer com que o usuário se interesse pelo produto, baixe o aplicativo e usufrua da promessa de estabelecer contatos com os usuários que desejar. No entanto, há raízes não comerciais e mais antigas para que determinados elementos culturais operem nessa dinâmica entre homens. Uma delas é que, convencionalmente, parte da dinâmica da masculinidade envolve a "conquista" 
como "caça" e como estratégia para a ampliação do número de parceirxs. A busca amorosa vista como "caça" é um dado cultural antes de ser um mero efeito mercadológico. O que as mídias digitais fizeram foi tornar isso mais visível e, talvez, potencializaram essa prática. Em suma, há uma questão de gênero que não pode ser esquecida e que permite questionar em que medida as convenções correntes sustentam a produção tecnologias que incentivam aos homens buscarem sexo e às mulheres amor nas novas mídias ${ }^{14}$.

Em geral, essas mesmas páginas oferecem instruções básicas de uso e, seguindo a legislação estadunidense, informações em profundidade sobre as regras de do uso, tais como a proibição que restringe a exposição de órgãos genitais, discurso de ódio, pedofilia e violência. São sempre reservadas seções específicas para a exposição detalhada dessas informações.

Com essa breve apresentação sobre a criação e a publicidade dos aplicativos na internet pretendo destacar que os três vendem as mesmas promessas de experiências, os mesmos corpos saudáveis e veiculam as mesmas mensagens ideológicas. Além disso, assim como as tecnologias de diversas ordens empregadas na construção dos aplicativos, os códigos e as convenções que circundam o desejo homoerótico também são irradiados a partir dos grandes centros urbanos e mantêm com eles uma estreita relação.

No caso da minha pesquisa, essa articulação encontra ressonância nos interlocutores e se se expressa sob a forma do desejo pela metrópole como sinônimo de autonomia, anonimato e liberdade (PADILHA, 2015). O desejo de metrópole é, também, desejo de autonomia, o mesmo que marca o uso dos aplicativos. Durante a pesquisa pude notar como muitos dos interlocutores - se não a maioria - são homens marcados por restrições morais, familiares, de mobilidade e que aprenderam a lidar e negociar com as normas sociais. Questões que tocam os direitos, a insegurança e a maior exposição à violência são fios que atravessam os usos das mídias digitais e, embora seja um tema ainda pouco ou quase nada abordado, podem oferecer um contraste entre as relação e questões que perpassam os contextos de busca por pessoas do sexo oposto.

\footnotetext{
14 Ainda que existam aplicativos similares para lésbicas atualmente eles não possuem tantas usuárias quanto os aplicativos gays e os heterossexuais como, por exemplo, o Tinder. Inclusive a oferta de aplicativos desse tipo é significativamente menor. Até hoje apenas encontrei dois aplicativos para lésbicas. Em contrapartida, muitos aplicativos voltados ao público heterossexual estão disponíveis, mas, em geral, são anunciados como ferramentas para fazer "novas amizades". Isso não quer dizer que as mulheres não se relacionem ou que não busquem, mas que possivelmente se relacionam mediante outras lógicas e a partir de outros marcos referenciais.
} 
Isto não é um manual de instruções: notas sobre a construção e consumo de perfis em três redes geosociais voltadas ao público gay

Esses elementos apontam para a difusão da internet como produção de um "espaço relacional" (McQUIRE, 2011) capaz de acelerar a troca de imagens, informações, códigos e simbolismos. No caso dos aplicativos, esse simbolismo recai enfaticamente sobre o texto e a imagem como mediadores das interações. Por fim, ao enfatizar o fato de que os aplicativos são produzidos em um contexto geograficamente situado, pretendo sublinhar as diferenças entre o contexto de produção e de recepção dessas tecnologias.

\section{Sobre buscas deambulatórias}

A construção dos perfis não se faz despregada das preocupações com a circulação das informações e da estética. Além disso, os aplicativos possuem uma dimensão arquitetural que extrai do usuário informações consideradas importantes para a interação na rede. Por assim dizer, o processo de construção de um perfil nos aplicativos elicita do usuário um conjunto de categorias pré-formatadas.

A própria infraestrutura do aplicativo extrai dados como peso, altura, idade, cor dos olhos, cor dos cabelos, tipo corporal e grau de pilosidade, e até mesmo dados que (con)fundem marcadores como raça, etnia e nacionalidade. Essas lacunas pré-formatadas acabam se convertendo em categorias consideradas fundamentais para a apresentação de si e mediante as quais os filtros de busca poderão atuar.

O historiador Adrian Forty (2007) examina como foi modelada a aparência dos bens de consumo nos duzentos anos que se seguiram à introdução da produção mecanizada. Focado nas relações entre o design e a sociedade europeia do século XVIII e XIX. Suas análises perseguem o modo como a sociedade foi apresentada às suas construções sociais e às suas ideologias cristalizados nos produtos da época. Embora o foco das análises de Forty não seja as mídias digitais, seus argumentos permitem questionar quais elementos estão em jogo quando se trata de produzir a legitimidade sobre os produtos, seus design e usos.

Baym (2013, p.16) aponta que, diferente das relações mantidas por outros meios, aquelas mantidas pelas mídias digitais são relações explicitamente rotuladas por uma "infraestrutura dos sistemas". O que Baym chama de infraestrutura dos sistemas poderia ser mais bem entendido na linguagem informacional como o layout ou, simplesmente, como sugiro, aspectos arquiteturais dos aplicativos e sites. Cada uma dessas mídias, bem como o 


\section{NORUS - v3, n.3, jan-jun 2015.}

próprio telefone celular contemporâneo, oferece aportes exclusivos, recursos, potencialidades e restrições para a comunicação. E, para compreendê-los sob esse aspecto, em profundidade, é necessário considera-los separadamente e, ao mesmo tempo, de forma holística.

Além disso, na busca por estabelecer contatos, as redes sociais digitais o fazem induzindo um tipo rotulação que antecipa o uso. Baym (2010) chama a atenção para o fato de que o Twitter@, sintetizado em mensagens curtas, usa o termo "seguidor", o Linkedin@, orientado para contatos profissionais, se vale de termos mais neutros como "contato" e "conexão" e Facebook@ permite a classificação da lista de "amigos" segmentada entre "contatos" ou "familiares".

Sherry Turkle, pesquisadora das mídias digitais, há quase duas décadas assinalava como A vida no ecrã (1997) progressivamente havia se convertido em um laboratório que nos permitia jogar e testar diversas experiências com a nossa própria identidade. Segundo ela, estas tecnologias produziram novos espaços de encenação, mas, em contrapartida, também engendram novas formas de exclusão e vigilância. Se aproximando de Judith Butler, ela mostra como mantemos com nossos avatares e perfis virtuais uma relação performativa.

Tomando de maneira crítica a separação artificial entre as dimensões on/offline, Turkle (1997) afirma que as identidades constituídas online são indissociáveis daquelas que constituímos offline. O que o chamado "mundo virtual" produz é uma ampliação em torno das possibilidades de atuação, encenação, apresentação e representação de si, permitindo que fantasias e desejos sejam acessados e vividos em um ambiente percebido como de suspensão da realidade ${ }^{15}$.

Levando em consideração o argumento de Landa (2009) sobre o dispositivo cultual do fitness é possível dizer que a sua expansão mundializada abarcou desde a construção de práticas, narrativas e espaços que, por sua vez, engendraram maneiras de ser e agir com tendências à visibilidade na existência social. Nesses cenários especulativos e corporais, os sujeitos devem inscrever-se em normativas e regras prescritas pelas tecnologias textuais, espaciais e subjetivas que encontram respaldo em um universo moral. Em suma, as tecnologias passam a funcionar em relação à figura do desviante e do normal - como modelo modelo, estereótipo e encarnação de todas as prescrições.

\footnotetext{
${ }^{15}$ Esse argumento poderia ser apresentado sob a sintética e irônica formulação feita pelo professor Jorge Leite Júnior: "não há nada que seja mais a sua cara, do que o seu perfil fake (falso)".
} 
Isto não é um manual de instruções: notas sobre a construção e consumo de perfis em três redes geosociais voltadas ao público gay

Considerando tais argumentos, não tomo os aplicativos como espaços naturalmente decorrentes da sofisticação das redes sociais, tampouco como espaços puramente simbólicos, mas como laboratórios midiáticos em que a subjetividade é especializada e testada estrategicamente se comunicando e capitalizando por meio de rigorosas técnicas de ocultamento, superexposição, vigilância e produção de prazer.

O fato de que esses espaços sejam imaginados não torna seus efeitos menos concretos. Illouz (2011, p.138) defende a tese de que "a imaginação, ou a utilização cultural e institucionalmente organizada da fantasia, não é uma atividade abstrata ou universal da mente. Tem antes uma forma cultural que precisa ser analisada". O argumento de Illouz pode se somar ao de Miskolci (2014, p.18) para quem "o impensável - leia-se uma sociedade não fundada na proibição das relações amorosas e sexuais entre pessoas do mesmo sexo - não está fora da cultura, antes dentro dela, apenas de forma dominada".

Nesse sentido, ao falar em uma "arquitetura" dos perfis, me refiro à infraestrutura dos sistemas como efeito discursivo de uma série de discursos especializados em elicitar do usuário as características imaginadas como fundamentais. Essas características são préformatadas pelos desenvolvedores respaldados em pesquisas empíricas desenvolvidas por profissionais das ciências psis e das ciências sociais. Portanto, são baseadas em categorias e pressupostos, tanto psicológicos, quanto culturais, sobre como compreender a si mesmo e como arquitetar a sociabilidade a partir da sociabilidade afetiva ou da compatibilidade sexual (PELÚCIO e MISKOLCI, 2008; ILLOUZ, 2011).

Essas pesquisas empíricas trouxeram para dentro dos sites e aplicativos as categorias empíricas das relações cotidianas pré-existentes às tecnologias. Esse elemento impede o argumento reducionista centrado na imposição-formatação a partir dos aplicativos. Do mesmo modo como ocorre com a versão computacional produzida pelo usuário, a arquitetura dos aplicativos respondem aos desejos, interesses e ideologias de uma época. Isso permite destacar a ligação que a arquitetura dos aplicativos mantém com outros regimes que difundem novas economias do desejo, do consumo, do segredo, aclimatados em um contexto de recepção das tecnologias.

Ao transformar a possibilidade da busca por parceiros diante do georreferenciamento, os aplicativos consolidaram um tropo erótico alternativo para representar a homossexualidade (PADILHA, 2015). O próprio regime espacial no qual operam os aplicativos é também uma 
tradução arquitetural das premissas de gênero que sustentam a construção dos sites de relacionamentos com suas funcionalidades, recursos e limitações. Para entender esse processo é necessário voltar ao processo de construção do perfil.

\section{Como converter-se em um perfil ou sobre como, onde, quando e por quem quero ser visto?}

Após o cadastro e a criação de uma senha pessoal - signos da segurança e da privacidade - o usuário deve escolher um apelido e, posteriormente, se assim desejar, selecionar uma fotografia que ilustre o perfil. Este processo envolve deliberações de diversas ordens que devem ser assumidas por quem deseja se converter no écran. A textualização, o enquadramento, ângulo e iluminação, passando pela seleção de uma dentre várias imagens até o tratamento proporcionado por programas especializados em filtros e melhorias, são exemplos ilustrativos das decisões envolvidas nesse processo de apresentação de si. Em geral, a busca por um tipo de "purificação imagética" é também parte desse processo de construir a si mesmo na rede (SIBILIA, 2015, p.189).

Embora a fotografia não seja obrigatória, perfis sem imagens convincentes tendem a ser desacreditados e previamente rejeitados por slogans tais como: "sem foto nem me escreva" ou "sem foto, sem papo". A fotografia e, mais especificamente, aquela que revela o rosto do usuário no perfil, por um lado, tende a ser lida como "mais autêntica" e, consequentemente, tem maiores chances de receber mensagens, especialmente daquelas pessoas que buscam abertamente ${ }^{16}$. Por outro lado, ter o rosto exposto no perfil pode afastar determinados usuários comprometidos com o sigilo. Em síntese, seja para mostrar ou para ocultar, "fotos são fundamentais" para criar interações mais críveis.

Em um artigo recentemente publicado, Beleli (2015, p.104) aponta que o "olhar, treinado pela câmera do celular e pelas imagens que circulam por variadas mídias, é um filtro para ver o Outro e imaginar a si mesma". Nessa mesma direção, a crítica feminista de Susan Sontag (1986, p. 15) sublinha que "as fotografias são uma gramática e, sobretudo, uma ética da visão".

\footnotetext{
${ }^{16}$ No caso específico da minha pesquisa de mestrado, interessada no segredo, pude notar diferenças significativas nos usos que faziam as pessoas que buscavam em segredo e aquelas que buscavam abertamente.
} 
Isto não é um manual de instruções: notas sobre a construção e consumo de perfis em três redes geosociais voltadas ao público gay

Para Sontag, as fotografias constituem meios de acesso à experiência que têm como principal efeito a ilusão de participação: "como cada fotografia é apenas um fragmento, o seu peso moral e emocional depende do conjunto em que se insere. Uma fotografia muda em função do contexto em que é vista" (p. 13). Mais do que isso, a própria realidade é "redefinida como um objeto para a exposição, como um registro para um exame minucioso, como um alvo para vigilância" (p. 4). Vistas dessa maneira as fotografias são experiências capturadas e a câmera é o o instrumento ideal da consciência na sua atitude aquisitiva. Dito isto, é possível afirmar que a disseminação das câmeras fotográficas acopladas às mídias digitais amplificou essa consciência de maneira jamais vista.

A socióloga marroquina Eva Illouz (2011, p.113) assinala que a produção de um perfil incita que os sujeitos construam uma "textualização da sua subjetividade". Ou seja, as mídias convidam as pessoas a se descreverem de forma objetiva e essa operação requer, simultaneamente, um refinamento de suas fantasias e de seus ideais. Assim, uma das novidades da internet é produzir um paradoxo que posiciona os sujeitos de maneira contraditória em um processo mediado pela tecnologia e que é, simultaneamente, a conjunção entre um subjetivismo intenso - que se expressa na descrição de características psicológicas e a intensificação de uma objetificação do encontro - como é a pessoa que desejo?

Entretanto, há que se considerar que a pesquisa de Illouz é justamente sobre os sites de relacionamento apresentados pela publicidade do Grindr@ como "repletos de questionários psicológicos complexos e enfadonhos". Esses sites produzem questionários que permitem, mediante algoritmos especializados no cálculo das probabilidades estatísticas em torno de afinidades, o cruzamento dessas informações alcançando resultados que funcionam como indicadores. Com frequência, a mesma operação é replicada por sites de compra em busca de consumidores.

A diluição dessa lógica nos aplicativos permite refletir sobre como a ênfase na textualização de si marcou um período específico da internet. Sugiro que, talvez, a ênfase textual tenha sido sobreposta pela imagem como efeito da proliferação de dispositivos acoplados aos equipamentos móveis, tais como câmeras e microfones.

De modo sintético, os sites que operam organizando possíveis parceiros o fazem por meio de uma aritmética das afinidades baseada em algoritmos. Essa aritmética dos relacionamentos se baseia em pesquisas empíricas produzidas por profissionais da sociologia, 


\section{NORUS - v3, n.3, jan-jun 2015.}

antropologia e psicologia. Em geral, essas pesquisas oferecem dados empíricos sobre formação de pares amorosos considerados bem-sucedidos e envolvem múltiplas teorias sobre afinidades e/ou compatibilidades sociais.

No entanto, paradoxalmente, é a abolição dessa aritmética que se converte na "autonomia dos usuários" celebrada pela publicidade dos aplicativos. Se os sites estudados por Illouz incitavam um tipo de subjetivismo intenso calcado autorreflexão como passo fundamental para a textualização de si, os aplicativos incitam um tipo de objetivismo em torno da imagem como texto.

Sharif Mowlabocus (2010), analisando as relações que os britânicos estabeleciam a partir do site Gaydar.com, aponta que a construção de um perfil é uma operação complexa que envolve vários níveis e inclui tanto uma dimensão subjetiva (como quero ser visto?), quanto uma dimensão objetiva (conhecer as funcionalidades da tecnologia). Em resumo, essa análise nos mostra como olhar um perfil é também avaliar o Outro sob o seu próprio ponto de vista. Além disso, essa relação converte o perfil em um ponto de mediação da autopercepção do sujeito com a percepção e apreciação externa. Isso ganha contornos específicos quando considerado o fato de que aqui, especificamente, trato de homens que buscam estabelecer relações com outros homens e que são bombardeados cotidianamente com estereótipos negativos sobre homossexualidade e os homossexuais. A construção de como se quer ser visto é também uma forma de busca de reconhecimento social (MISKOLCI, 2015).

Os aplicativos que operam com base em georreferenciamento dependem fundamentalmente do interesse de um usuário sobre o outro para que se iniciem interações. Nesse contexto, formular uma apresentação de si atraente e crível é fundamental para seduzir o interesse dos outros usuários e iniciar novas interações. Tenho apontado aqui alguns elementos que permitem formular uma compreensão sobre quais elementos são considerados atraentes e por quais razões.

As categorias pré-formatadas que o aplicativo oferece para que o usuário descreva a si mesmo podem, posteriormente, (se assim ele desejar) converterem-se em "filtros de busca" operando como um mecanismo prévio na seleção de possíveis interações/parceiros. É essa dimensão pré-formatada que tenho chamado de arquitetura dos perfis. Com isso, quero assinalar também o desenho projetado para que o usuário se (re)crie a partir das lacunas estabelecidas pelos desenvolvedores. Os usos dessas lacunas incluem dados como altura, cor, 
Isto não é um manual de instruções: notas sobre a construção e consumo de perfis em três redes geosociais voltadas ao público gay

peso, raça/etnia, preferências eróticas/sexuais, entre outros. Quando convertidas em filtros de busca, essas características corroboram com o argumento de Illouz (2012) para quem as mídias digitais incentivam uma uma crescente intelectualização da busca amorosa. Nesse aspecto, os aplicativos apenas enfatizam um processo já em andamento e verificado em pesquisas empíricas anteriores.

No caso do Grindr@, o aplicativo adota como logomarca uma máscara preta sobreposta a uma tela amarela. Segundo conta o seu criador em uma entrevista para um portal de internet ${ }^{17}$, o sentido da máscara foi imaginado colocando a comunidade gay em analogia com uma tribo urbana, ou melhor, como uma "comunidade de tribos unificadas" que podem ter o sua compreensão alargada se entendidas como segmentos sociais ou comerciais.

Segundo Simkhai conta, as pesquisas de mercado que orientaram a produção da logomarca do produto identificaram na máscara uma suposta representatividade simbólica que permitiria unificar as "diferentes tribos que compõem a comunidade gay". Este aplicativo coloca em circulação uma classificação que divide a comunidade gay em doze "tribos". Essa segmentação, como já foi dito, são geradas em relação com a pornografia gay convencional, a mesma que tem em Los Angeles e San Francisco seus grandes centros de produção e distribuição.

\begin{tabular}{|c|}
\hline $\mathbf{1 2}$ tribos do Grindr $\odot$ \\
\hline Bear - Urso \\
\hline Clean-cut - Bem-cuidado/limpo, \\
\hline Daddy - Papai \\
\hline Discreet - Discreto \\
\hline Geek - Nerd \\
\hline Jock - Atleta \\
\hline Leather - Adeptos de trajes em couro \\
\hline Otter - Lontra, \\
\hline Poz - Sigla para pessoas HIV+ \\
\hline Rugged - Rústico, \\
\hline Trans - transexual \\
\hline Twink - Jovem, com frequência, sem pêlos corporais \\
\hline
\end{tabular}

${ }_{17}$ Entrevista integralmente disponível em: <http://gonline.uol.com.br/2011/blog/2012/12/04/graos-de-amor-2/>. 
A máscara, a partir de uma interpretação livre, alude à ideia de que o aplicativo permite ao usuário mascarar-se, portanto, construir performativamente uma imagem de si de acordo com o modo como deseja ser visualizado, mantendo controlada a "informação social" (GOFFMAN, 1988, p. 101). O fato de homossexuais desenvolverem técnicas e estratégias para ocultar seus desejos e suas práticas possui razões históricas.

Os diversos discursos que estigmatizaram a homossexualidade ao longo do tempo fizeram do segredo a principal estratégia empregada pelas pessoas que buscavam controlar a circulação de "informações destrutivas" (GOFFMAN, 1988, p.104). As máscaras ou as reuniões em sociedades (ou tribos) secretas são, nesse sentido, práticas atualizadas que se passam agora no contexto das mídias digitais.

O Grindr@ não possui uma interface traduzida para a língua portuguesa, desse modo, todos os trechos apresentados foram por mim traduzidos em termos que julguei como equivalentes. Essas classificações não são produzida num vácuo cultural. Mowlabocus (2010) observa que as categorias oferecidas pelos aplicativos para que os sujeitos representem a si mesmos são forjadas em continuidade com as convenções do universo da pornografia gay convencional e do mercado sendo, portanto, desde sua criação, tributárias desses ideários culturais.

\begin{tabular}{|c|}
\hline Estrutura corporal \\
\hline Toned - Torneado \\
\hline Average - Comum \\
\hline Large - Grande \\
\hline Muscular - Musculoso \\
\hline Slim - Magro \\
\hline Stolcky - Parrudo \\
\hline
\end{tabular}

\begin{tabular}{|c|}
\hline Características étnico-raciais \\
\hline Asian - Asiático \\
\hline Black - Negro \\
\hline Latino \\
\hline Middle eastern - Oriente médio \\
\hline Mixed - Mestiço \\
\hline Native american - Nativo americano \\
\hline White - Branco \\
\hline Other - Outros \\
\hline South asian - Sul asiático \\
\hline
\end{tabular}


Isto não é um manual de instruções: notas sobre a construção e consumo de perfis em três redes geosociais voltadas ao público gay

\begin{tabular}{|c|}
\hline Objetivo da busca \\
\hline Chat - Conversa \\
\hline Dates - Encontros \\
\hline Friends - Amigos \\
\hline Networking - Contatos \\
\hline Relationship - Relacionamentos \\
\hline $\begin{array}{c}\text { Right now }- \text { Fast-foda/sexo } \\
\text { imediato e sem compromisso }\end{array}$ \\
\hline
\end{tabular}

\begin{tabular}{|c|}
\hline Status de relacionamento \\
\hline Single - Solteiro \\
\hline Dating - Namorando \\
\hline $\begin{array}{c}\text { Exclusive - Possui um relacionamento } \\
\text { oficial sem mais ninguém evolvido } \\
\text { Committed - Engajado em um } \\
\text { relacionamento monogâmico, mas } \\
\text { flexível }\end{array}$ \\
\hline $\begin{array}{c}\text { Partnered - Engajado em um } \\
\text { relacionamento sério }\end{array}$ \\
\hline $\begin{array}{c}\text { Engaged - Noivo } \\
\text { Married - Casado }\end{array}$ \\
\hline $\begin{array}{c}\text { Open relationship - Engajado em uma } \\
\text { relação aberta }\end{array}$ \\
\hline
\end{tabular}

É mediante esse conjunto de categorias, atualmente operativas principalmente nos aplicativos, mas não somente, que os homens avaliam e são avaliados por possíveis parceiros. Sob esse aspecto, os perfis se converteram em um espaço de inteligibilidade e reconhecimento mútuo sob tais categorias. O usuário pode ou não preencher o formulário de acordo com o seu desejo, do mesmo modo que pode ou não ser aplicá-los como filtros na busca.

No caso do no Scruff( , que conta com uma versão traduzida para língua portuguesa, o questionário teve suas categorias aproximadas da realidade brasileira. Nele o usuário segue o mesmo roteiro: a criação de uma senha de acesso, um nome situacional, informa idade, altura, peso, pilosidade corporal (liso, um pouco peludo, peludo, muito peludo), raça/etnia/ regionalidade de origem (asiático, branco, hispânico/latino, indiano, mestiço, nativo americano, negro, das ilhas do pacífico, do oriente médio), identifica suas comunidades e a de seus interesses (sou/procuro - urso, músculo, atleta, garoto, coroa, universitário, nerd, militar, discreto, HIV+, em busca de coroas, em busca de ursos, transexual, couro) e a sua disponibilidade (para - amizades, relacionamentos, encontro casual, encontros, conversa apenas ou contatos).

As demais seções devem ser preenchidas textualmente e dispõe de lacunas para serem preenchidas com informações sobre a busca, os interesses e a localização geográfica - cidade/ 


\section{NORUS - v3, n.3, jan-jun 2015.}

estado/país. Tanto o Hornet@, quanto o Scruff(C), em suas versões gratuitas, disponibilizam o “modo viagem", para pessoas em trânsito. Também é permitido vincular ao perfil links que possibilitam o acesso para outras redes sociais digitais como, por exemplo, Instagram $\odot$ e Facebook@.

A logomarca do Hornet $(\subset$ é ilustrada com a imagem de uma "vespa" formada por um tangram ${ }^{18}$. A imagem talvez se torne mais ilustrativa se for levado em consideração o fato de que este aplicativo inovou ao permitir que o os usuários explorassem outras regiões sem sair do lugar. Como uma "vespa", significado da palavra "hornet", esse aplicativo permitiu aos usuários um deslocamento mais veloz e a invisível ${ }^{19}$. De outro modo, na língua inglesa existe uma homofonia entre as palavras "hornet" (vespa) e "horny" que significa "tesão".

Após inserir a fotografia e o apelido, é possível escolher um título para o perfil elaborando, em seguida, uma breve descrição de si que pode conter informações sobre a pessoa ou sobre preferências. Dados como idade, peso, altura, etnia (asiático, negro, latino, árabe, pardo, nativo americano, asiático do sul, branco ou outro), relacionamento (solteiro, enrolado, numa relação aberta, namorando), o que procuro (conversar, encontros, amigos, networking, namoro) são as categorias pré-formatadas e oferecidas pelo aplicativo.

Para Mowlabocus (2010) essas categorias são convenções forjadas e compartilhadas no universo da subcultura gay e que estão relacionadas com uma técnica de classificação de tipos corporais, faixas etárias e fetiches. Por assim dizer, os aplicativos reinventaram essa linguagem de uma forma específica e que agora se converte em mecanismos de busca e filtragem. Ele ainda aponta que as mídias voltadas para homens gays mantêm uma forte ressonância com as narrativas produzidas por outras mídias como o cinema, a pornografia convencional e a propaganda publicitária. Este argumento destaca o caráter multidimensional dessas tecnologias e o modo como são constituídas em permanente contato.

Mais do que isso, as mídias permitiram a constituição de redes que possibilitaram falar sobre o desejo, assim como intensificaram a troca de "imagens" outras sobre a "homossexualidade" e sobre "como ser gay" em escala global. Na medida em que ampliam o

\footnotetext{
18 "Tangram" é o nome dado a um tipo de quebra-cabeça chinês composto de sete peças recortadas em formas geométricas com as quais, sem sobreposição, é possível formar uma variedade de figuras.

${ }^{19} \mathrm{O}$ Hornet foi um dos primeiros aplicativos georeferenciados que permitiu aos usuários localizar e contatar os perfis de pessoas em regiões específicas. Aplicativos como o Grindr, em sua versão gratuita, permite que o usuário contate apenas um número restrito de pessoas.
} 
Isto não é um manual de instruções: notas sobre a construção e consumo de perfis em três redes geosociais voltadas ao público gay

contato e a interação entre as pessoas, para Mowlabocus, trouxeram um aspecto positivo, ao colocarem em circulação um novo vocabulário para lidar com o desejo homoerótico mais ligado à "identidade" do que aos tropos da "patologia" e da "vergonha"20. Esse elemento permite compreender por quais razões a busca parceiros "másculos" e "bonitos" é tão enfática nessas redes.

Estratégias desse tipo podem assinalar também a busca por normalidade e reconhecimento social. As mídias digitais servem também para que os usuários busquem parceiros que sejam socialmente reconhecidos como bonitos e desejáveis. Há uma lógica coletiva nessa busca individual que ainda foi pouco explorada. Uma pista investigativa pode ser a de que nossa sociedade demanda de gays e afins que tenham pares mais socialmente reconhecíveis, inclusive para se desvencilhar das convenções estigmáticas.

A socióloga Mary L. Gray (2009), investigando as mídias a partir do Kentucky, no interior dos Estados Unidos da América, sublinha que a internet apresenta, para muitos/as jovens daquela localidade, uma oportunidade de viverem seus desejos sem o risco de exposição (2009, p.129). Em diversos casos, seus/suas informantes tiveram a primeira experiência de cruising/hookup ${ }^{21}$ através da rede. Vale lembrar que há em comum o fato de que as relações nessas cidades se dão em um nível onde "todos se conhecem", até mesmo "estranhos são familiares".

Sob esse aspecto, traçando um paralelo com o cotidiano das pequenas cidades do interior de São Paulo, onde é comum que as pessoas se classifiquem como "conhecidos de vista", é possível inferir que, nesses contextos, as pessoas são frequentemente reconhecidas como "o filho de fulano" ou "primo de beltrano" deixando, portanto, pouca margem para o reconhecimento da legitimidade de formas outras de expressão do desejo que não aquelas moralmente sancionadas.

Com isso é possível argumentar que o cruising é uma prática imaginada majoritariamente em ambientes metropolitanos mais propícios ao anonimato. No interior,

\footnotetext{
20 Esta formulação me foi apresentada por Mowlabocus em um encontro pessoal durante o II Seminário Internacional Gênero, Sexualidade e Mídias Digitais, realizado em outubro de 2013 na Faculdade de Arquitetura, Artes e Comunicação da Universidade Estadual Paulista - Júlio de Mesquita Filho (UNESP/Bauru).

${ }^{21} \mathrm{O}$ cruising é descrito por Perlongher como a "perambulação, mais ou menos prolongada, pelas áreas da cidade tendentes a serem transitadas por homens dispostos ao prazer e às diversões" (2008, p. 167). Por sua vez, Miskolci caracteriza a cultura do hookup pelo "predomínio de contatos sexuais sem compromisso que viabilizam uma vida sexual mais intensa, que pode levar ou não à criação de laços mais duradouros e estáveis" (2014, p.273). Ainda segundo esse autor, o hookup atualiza as antigas formas de busca sob um mecanismo higienizado de busca através das mídias.
} 
onde o número de pessoas conhecidas tende a ser maior, o sexo sem compromisso é um desejo irrealizável se comparado às metrópoles.

Ao longo da minha pesquisa, situada no interior de São Paulo e, portanto, em um contexto de recepção dessas tecnologias, percebi que as mídias podem descentrar os antigos predicados empregados para nomear e qualificar o desejo homossexual. Por vezes, o uso dessas tecnologias coloca em circulação uma outra gramática que, eventualmente, permite posições contestatórias diante das suas expressões hegemônicas (PADILHA, 2015). No entanto, ainda cabe avaliar em que medida esse "novo vocabulário" consegue se desprender dos ideais nacionais que circundam o desejo no contexto de produção desses aplicativos.

Além disso, há que se considerar o fato de que, ao reservarem tecnologias e aplicativos especificamente voltados para pessoas não heterossexuais, como é o caso desses aplicativos, as mídias digitais acabam funcionando como prolongamentos do dispositivo cultural enredado pelos banheiros, saunas e outros espaços destinados à "pegação" mantendo, assim, intocada a percepção heteronormativa sobre o espaço público. O que se produz nas mídias digitais é um outro tipo de busca de parceiros sexuais marcada por filtros.

A seletividade dos aplicativos cria uma afinidade eletiva com o ambiente do interior. Isso não quer dizer que as pessoas não desejem sexo sem compromisso, mas que as dinâmicas e as estratégias plausíveis em locais onde impossibilidade do anonimato existe podem incentivar outros tipos de busca/relação.

\section{Algumas considerações finais}

Apresentar-se como homem gay ou homossexual nos perfis produzidos na rede equivale a uma afirmação identitária performativa que cola os sujeitos a uma identidade de gênero (homem) e sexual (gay/homossexual) que aciona um imaginário estético e ético sobre "como ser gay". Por outro lado, há que se considerar o fato de que assumir-se "homossexual", além de um projeto com marcas de classe que remetem aos segmentos mais abastados da sociedade brasileira, implica (ainda!), em diversos contextos, em riscos de várias ordens. Especificamente, entre os meus interlocutores, as demandas e pressões pela heterossexualidade com as quais se confrontam na vida cotidiana, seja de maneira direta ou indireta, enredam um jogo de visibilidade e negociação (PADILHA, 2015). 
Isto não é um manual de instruções: notas sobre a construção e consumo de perfis em três redes geosociais voltadas ao público gay

Meu propósito ao tomar elementos como a propaganda e a dimensão arquitetural dos perfis encontra inspiração nos escritos de Stuart Hall (2010) e na sua proposta de uma teoria da articulação. Este autor sugere que a teoria da articulação permite visualizar como os elementos ideológicos, em certas condições, ganham coerência dentro do discurso, comportando, ao mesmo tempo, questionamentos sobre a forma como determinados elementos se articulam ou não em conjunturas específicas.

A teoria da articulação se pergunta como uma ideologia descobre seu sujeito, antes de perguntar como o sujeito pensa os necessários e inevitáveis pensamentos que pertencem a ela. A teoria nos permite pensar como uma ideologia nos empodera nos capacitando para começar a fazer algum sentido ou inteligibilidade de sua situação histórica, sem reduzir essas formas de inteligibilidade a uma ligação sócioeconômica ou de classe ou a sua posição social (HALL, 2010, p.85-86, grifos do autor - tadução minha).

Hall não toma o poder apenas em termos de coerção ou restrição. Nesse caso, a percepção é ampliada para abarcar o poder da em termos culturais, sob os simbolismos da representação. Dessa perspectiva, interessa compreender a dinâmica de poder que confere a possibilidade de marcar, significar e classificar. Isso inclui também o poder de representar algo ou alguém de certa maneira dentro de um certo "regime de representação". É nesse sentido que procuro expor o exercício de poder simbólico que, por meio de práticas representacionais publicitárias, estereotipam as classificações disponíveis para os usuários nesses aplicativos.

Néstor Perlongher (2008), observando o contexto paulistano, sugere que a rua é um espaço de errância sexual por onde os sujeitos à deriva se abrem ao novo durante a procura. Em suma, "a paquera homossexual constitui, no fundamental, uma estratégia de procura de parceiro sexual adaptada às condições históricas de marginalização e clandestinidade dos contatos homossexuais" (PERLONGHER, 2008, p. 166). Daí o papel decisivo desempenhado, em muitos casos, pelo segredo e pelo grupo.

No tocante às relações homoeróticas masculinas, historicamente enlaçadas ao segredo, em termos tecnológicos, a internet comportou uma profusão de sítios, plataformas e aplicativos especializados na busca por parceiros sexuais e/ou amorosos. Esse espaço relacional intensificou as trocas simbólicas e colocou em circulação vocabulários e estilos de vida que expandiram os horizontes aspiracionais, permitindo rearranjos nas significações préexistentes.

Esta circulação não é estabelecida apenas pelos desenvolvedores. De outro modo, ela 


\section{NORUS - v3, n.3, jan-jun 2015.}

encontra ressonância nos usuários. As imagens, as propagandas e os comentários na mídia a respeito dos aplicativos vendem como "novas" estratégias, simbologias, estéticas e um repertório para qualificar e viver o desejo. Esse repertório ao entrar em circulação articulado à produção imagética dão outros parâmetros de inteligibilidade à dinâmica de visibilidade.

As mídias permitiram a constituição de redes que possibilitaram falar sobre o desejo e ao mesmo tempo intensificaram a troca de "imagens" outras sobre a "homossexualidade" e sobre "como ser gay" que circulam em escala global. Nos contextos de recepção, estas mídias descentram os predicados empregados para qualificar "o desejo homossexual" (HOCQUENGHEM, 2009) permitindo, em diversas situações, posições contestatórias diante das suas expressões da sexualidade hegemônica (MOWLABOCUS, 2010).

No entanto, ao reservarem ambientes virtuais especificamente voltados para não heterossexuais, como é o caso dos aplicativos, as mídias digitais acabam funcionando como um prolongamento dos banheiros, saunas e outros espaços destinados à pegação. Nesse movimento permanece intocada a percepção heteronormativa sobre o espaço público. No entanto, esse fato explicita que a ordem social mantém condições injustas e violentas para a vivência de relações com pessoas do mesmo sexo. Ao incentivar meios de busca alternativos (inclusive digitais), diante do espaço público percebido como exclusivamente heterossexual., os aplicativos não são mais do que uma mera extensão dos espaços de pegação. De outro modo, eles modificam profundamente a dinâmica da busca.

Analisando os perfis e a ênfase em características como discrição e masculinidade, algo parece ter permanecido em comum desde a pesquisa de Perlongher até os nossos dias: a busca nessas redes digitais, tal como na rua, ainda é guiada pelo desejo do "homem de verdade". Em outras palavras, a masculinidade ainda é o fetiche que guia tanto quem busca, quanto quem se apresenta. A busca por masculinidade e discrição pode ser melhor entendida levando em consideração a igualdade de direitos e segurança no espaço público não estão dadas para pessoas que desejam fora do marco heteronormativo.

Os aplicativos criaram um espaço para a publicidade de si. Nos aplicativos todos se anunciam e, tal como acontecia com os michês de Perlongher, precisam dar conta das demandas da entrevista. Em outras palavras, é preciso negociar com o desejo de quem busca. A grande demanda por corpos másculos, construídos à base de exercícios físicos e expostos 
Isto não é um manual de instruções: notas sobre a construção e consumo de perfis em três redes geosociais voltadas ao público gay

em fotos eróticas, parece ter borrado as fronteiras visíveis que antes permitiam diferenciar aqueles que vendem daqueles que compram.

Se antes os códigos eram deslocados marcando territórios simbólicos dispostos pela cidade, agora são traduzidos enquanto trafegam pelo espaço relacional das mídias digitais. Embora os contextos locais decodifiquem a linguagem, ao compor um perfil nesses aplicativos, o usuário se vê irremediavelmente preso a uma entrevista que, embora não seja mais a do cliente, ainda considera fundamental extrair dele informações sobre sua corporalidade, métrica e prosa.

Ainda assim, algo parece ter mudado: os critérios valem para ambos. O cliente, mesmo sem ser considerado socialmente bonito/desejável, poderia contratar o michê. Há uma horizontalidade nas buscas atuais em que ambos os potenciais parceiros têm que passar na entrevista.

Ao se decompor em medidas, preferências e ilustrado por uma imagem atrativa, o usuário se apresenta como se fosse um produto que, entre tantos outros, precisa soar atrativo aos olhos de quem consome. Nos depoimentos das pessoas com quem conversei e nas descrições dos perfis que observei, não são raras as ocasiões em que os usuários mencionam a "sensação" compartilhada de que estão em disputa em um "mercado". Alguns, de maneira mais crítica, ironizam a concorrência e a construção dos perfis como produtos que esperam até serem consumidos. Entretanto, a questão de gênero é um pano de fundo que complexifica a compreensão dos aplicativos. O homem que quer "consumir" o outro/sexo com o outro, agora também tem que negociar sua corporalidade, já que agora nem todos os corpos são disponíveis.

Para os michês de Perlongher (2008) os anúncios delineados na carne sintetizavam os componentes que eram valorizados na busca. A corporificação do desejo, como mostra este autor, acontecia na entrevista que situava o michê sob o escrutínio do cliente com suas demandas. Nesse caso, a "masculinidade viril" (p. 255) era a mercadoria que estabelecia o valor na negociação e, principalmente, o que despertava o interesse do cliente sobre o michê.

Como sintetizam Miskolci e Pelúcio (2008, p. 19), no diálogo via internet, a antiga "entrevista" foi abreviada pela velocidade das interações virtuais, mas, do mesmo modo, se manteve o desejo pelo "homem de verdade" no centro das demandas. Em continuidade com estas análises, é possível sugerir que a internet disseminou o protocolo da entrevista como 


\section{NORUS - v3, n.3, jan-jun 2015.}

prática corrente na busca por parceiros e que, em linhas gerais, a linguagem do mercado foi estendida tanto entre as relações hétero quanto homoeróticas, em especial, para aqueles e aquelas que atualmente passaram a deter agência sexual e amorosa buscando parceiros online. (ILLOUZ, 2011; MISKOLCI, 2014).

A partir do que foi exposto, sugiro que, se os aplicativos incitam uma ampliação das possibilidades e experiências com as identidades, o fazem acionando de um conjunto de interpelações pré-formatadas que colocam no centro da apresentação de si a fotografia e a corporalidade decomposta em um sistema classificatório reinventado a partir das taxonomias da pornografia gay mainstream. Ampliação da agência sexual que inseriu recentemente alguns grupos que historicamente não podiam paquerar - ou só podem em discrição - em um mercado segmentado e com regras muito duras, mas que ainda assim apresenta avanços em relação ao que estava dado no passado.

A dimensão performativa implícita à atividade de "converter-se" em um perfil permite analisar como a internet viabiliza uma ampliação em torno das possibilidades de atuação e encenação em volta de práticas e identidades que reconfiguram os ideais, as fantasias, inventando outras convenções sobre o desejo e, nesse caso, sobre a masculinidade.

Para alguns dos homens com quem mantive contato, a partir do uso das mídias digitais, a homossexualidade pôde ser comunicada e vivida de maneira distinta do que se passava com as gerações anteriores. A partir do trabalho de campo, destaco que a busca pelo segredo e pela discrição são prerrogativas, em especial, para os homens com cerca de 30 anos de idade. Visto a contrapelo, é possível inferir que, para os homens mais jovens, o desejo homoerótico e a homossexualidade não são mais compreendidos sob os tropos da "patologia" e da "insanidade". Em suma, para as gerações mais novas, as mídias digitais colocaram um vocabulário em circulação que permite um sentimento de "normalidade" e que aciona outros simbolismos globais significados de maneira diferente e mais positiva do que as gerações anteriores.

Ainda que, em muitos contextos, permaneça a necessidade de negociar sua sexualidade com a família, o trabalho e o ambiente educacional, esses homens podem agora se perceber a partir de uma gramática que adiciona outros predicados ao desejo. A "discrição" exigida é muito diferente da "marginalidade" da era do cruising. Os relacionamentos e casamentos de fachada e outros componentes do antigo "armário homossexual", embora ainda 
Isto não é um manual de instruções: notas sobre a construção e consumo de perfis em três redes geosociais voltadas ao público gay

sirvam de suporte à heteronormatividade, são refletidos de maneira crítica apresentando transformações nos horizontes aspiracionais narrados pelos usuários.

Remeter o título deste artigo ao fato de que não se trata de um manual de instruções foi uma estratégia pensada a partir das minhas interações no campo. Com certa frequência meus interlocutores de pesquisa buscavam em textos acadêmicos explicações para "o que não deu certo" em suas interações nos aplicativos. Embora este texto não seja um manual de instruções, as questões aqui abordadas - assim espero - talvez possam delinear os contextos hostis às expressões do desejo homoerótico e as restrições que ainda permeiam o espaço público iminentemente imaginado como naturalmente heterossexual.

\section{Referências bibliográficas}

AULADELL, Felip Vidal. Joan W. Scott y Eva Illouz en la agencia de publicidad: aportaciones para el análisis de la noción de experiencia en el discurso publicitário. Daimon, Revista Internacional de Filosofía, n. 63, p.175-190, 2014.

BAYM, Nancy K. Personal Connections in the Digital Age. Cambridge: Polity Press, 2010.

Social Networks 2.0. In: M. Cosavo e C. Ess (orgs). The Handbook of Internet Studies. Oxford: Wiley-Blackwell, 2013.

BELELI, Iara A. Corpo e identidade na propaganda. Revista de Estudos Feministas, v. 15 n.1, p. 193-215, 2007.

Campinas , n. 44, p. 91-114, jun. 2015.

BUTLER, Judith. Cuerpos que importan: sobre os limites materiales y discursivos del "sexo". $1^{\text {a }}$ ed. Buenos Aires: Paidós, 2002.

FOUCAULT, Michel. Vigiar e punir: nascimento da prisão. Petrópolis, Vozes, 1987.

GADELHA, Kacyano Barbosa. Para além da "pegação": performatividade e espacialidade na produção de materialidades sexuais online. Áskesis - Revista dxs discentes do Programa de PósGraduação em Sociologia da UFSCar (Dossiê: No Truque: perspectivas queer tropicais), São Carlos, v.4, n.1, 2015 (no prelo).

GOFFMAN, Erving. Estigma: notas sobre a manipulação da identidade deteriorada. $4^{\mathrm{a}}$ ed. Rio de Janeiro: Editora Guanabara, 1988.

GRAY, Mary L. Out in the Country: Youth, Media, and Queer Visibility in Rural America. New York University Press, 2009.

HALL, Stuart. Sin garantías: trayectorias y problemáticas en estudios culturales. Tradução e organização de Eduardo Restrepo, Catherine Walsh e Víctor Vich. Instituto de estudios sociales y culturales Pensar. Quito: Universidad Javeriana, Instituto de Estudios Peruanos, Universidad Andina Simón Bolívar sede Ecuador, 2010.

HOCQUENGHEM, Guy. El deseo homosexual. España: Melusina, 2009. 
ILLOUZ, Eva. O amor nos tempos do capitalismo. Rio de Janeiro: Zahar, 2011.

Por qué duele el amor. Una explicación sociológica, Buenos Aires, Katz Editores, 2012.

LANDA; María Inés. Las tramas culturales del Fitness en Argentina: los cuerpo activos del ethos empresarial emergentes. $344 \mathrm{f}$. Tese (Doutorado em Literatura Comparada), Barcelona: Universidad Autónoma de Barcelona, 2011.

Subjetividades y consumos corporales: un análisis de las prácticas del fitness em España e Argentina. Razón y Palabra, Instituto Tecnológico y de Estudios Superiores de Monterrey Estado de México, México, n.69, jul-ago, 2009.

LAURETIS, Teresa. La tecnologia del género. Trad. Ana María Bach y Margarita Roulet. Revista Mora, n.2, p. 6-34, nov. 1996.

McQUIRE, Scott. A casa estranhada. Revista do Programa de Pós-graduação da Escola de Comunicação da UFRJ (Dossiê: cidades midiáticas), Rio de Janeiro, v. 14, n. 1, p. 27-66, 2011.

MISKOLCI, Richard; PELÚCIO, Larissa. Esse não mais obscuro negócio do desejo (Prefácio). In: PERLONGHER, Néstor. O negócio do michê: a prostituição viril em São Paulo. São Paulo: Editora Perseu Abramo, 2008.

MISKOLCI, Richard. A Gramática do Armário: notas sobre segredos e mentiras em relações homoeróticas masculinas mediadas digitalmente. In: PELÚCIO, Larissa et al. (orgs.). Olhares plurais para o cotidiano: gênero, sexualidade e mídia. 1ª ed. Marília: Cultura Acadêmica, p.35-55, 2012.

San Francisco e a nova economia do desejo. Lua Nova, São Paulo, n. 91, p. 269-295, 2014.

"Discreto e fora do meio" - Notas sobre a visibilidade sexual contemporânea. Cadernos Pagu, Campinas, n. 44, p.61-90, jun., 2015.

MOWLABOCUS, Sharif. Gaydar Culture: gay men, technology and embodiment in the Digital Age. London: Ashgate Publishing, 2010.

PAASONEN, Susanna. Online Pornography. Ubiquitous and effaced. In: M. Cosavo e C. Ess (orgs). The Handbook of Internet Studies. Oxford: Wiley-Blackwell, 2013.

PADILHA, Felipe. O Segredo é a Alma Do Negócio: mídias digitais móveis e a gestão do desejo homoerótico entre homens na região de São Carlos. 120 f. Dissertação (Mestrado em Sociologia). Programa de Pós-Graduação em Sociologia da UFSCar, Universidade Federal de São Carlos, São Carlos. 2015.

PERLONGHER, Néstor. O negócio do michê: a prostituição viril em São Paulo. São Paulo: Editora Perseu Abramo, 2008.

SIBILIA, Paula. A nudez autoexposta na rede: deslocamentos da obscenidade e da beleza?. Cadernos Pagu, Campinas, n. 44, p. 171-198, jun. 2015.

SONTAG, Susan. O heroísmo da visão. In: Dom Quixote, 1986. (Coleção Arte e Sociedade, n. 5).

Ensaios sobre a fotografia. Lisboa: Publicações

TURKLE, Sherry. A vida no ecrã: a identidade na era da internet. Lisboa: Relógio d'Água, 1997.

WAGNER, Roy. A invenção da cultura. São Paulo: Cosac Naify, 2010. 